\title{
Extracellular Protons Acidify Osteoclasts, Reduce Cytosolic Calcium, and Promote Expression of Cell-Matrix Attachment Structures
}

\author{
Anna Teti, „‡ Harry C. Blair," Paul Schlesinger, ${ }^{5}$ Maria Grano, ${ }^{\ddagger}$ Alberta Zambonin-Zallone, ${ }^{\ddagger}$ Amold J. Kahn," \\ Steven L. Teitelbaum," and Keith A. Hruska** \\ Departments of ${ }^{* *}$ Medicine and ${ }^{*}$ Pathology, Jewish Hospital at Washington University Medical Center, St. Louis, Missouri 63110; \\ $\S$ Department of Biological Sciences, Washington University School of Dental Medicine, St. Louis, Missouri 63110; ${ }^{\ddagger}$ Institute of Human \\ Anatomy, University of Bari, Bari, Italy; "Pediatric Research Institute, St. Louis University Medical Center, St. Louis, Missouri 63110; \\ and 'Shriners Hospital for Crippled Children, St. Louis, Missouri 63131
}

\begin{abstract}
Because metabolic acids stimulate bone resorption in vitro and in vivo, we focused on the cellular events produced by acidosis that might be associated with stimulation of bone remodeling. To this end, we exposed isolated chicken osteoclasts to a metabolic (butyric) acid and observed a fall in both intracellular pH and cytosolic calcium $\left(\left[\mathrm{Ca}^{2+}\right]_{i}\right)$. These phenomena were recapitulated when bone resorptive cells, alkalinized by $\mathrm{HCO}_{3}^{-}$ loading, were transferred to a bicarbonate-free environment.

The acid-induced decline in osteoclast $\left[\mathrm{Ca}^{2+}\right]_{i}$ was blocked by either $\mathrm{NaCN}$ or $\mathrm{Na}_{3} \mathrm{VO}_{4}$, in a $\mathrm{Na}^{+}$-independent fashion, despite the failure of each inhibitor to alter stimulated intracellular acidification. Moreover, $\mathrm{K}^{+}$-induced membrane depolarization also reduced cytosolic calcium in a manner additive to the effect of protons. These findings suggest that osteoclasts adherent to bone lack functional voltage-operated $\mathrm{Ca}^{2+}$ channels, and they reduce $\left[\mathrm{Ca}^{2+}\right]_{i}$ in response to protons via a membrane residing Ca-ATPase. Most importantly, acidosis enhances formation of podosomes, the contact areas of the osteoclast clear zone, indicating increased adhesion to substrate, an early step in bone resorption. Thus, extracellular acidification of osteoclasts leads to decrements in intracellular pH and calcium, and appears to promote cell-matrix attachment.
\end{abstract}

\section{Introduction}

Bone resorption is a multistep process sequentially involving attachment of osteoclasts to bone and creation of an isolated compartment at the site of matrix dissolution (1-4). Bone degradation is accomplished by acidification of the resorptive compartment leading to a milieu in which an osteoclast-secreted collagenolytic enzyme is active $(1,2)$. Thus, attachment of the osteoclast to bone, forming an extracellular compartment subsequently acidified, is pivotal to matrix resorption.

The studies described herein focus on the effect of acidification on osteoclasts. Metabolic acid is known to stimulate bone resorption in vitro and in vivo (5-8), but the mechanism is controversial. In addition, recent studies have reported that

Address reprint requests to Dr. Keith A. Hruska, Department of Medicine, Renal Division, Jewish Hospital at Washington University Medical Center, 216 South Kingshighway, St. Louis, MO 63110.

Received for publication 18 January 1989 and in revised form 25 April 1989.

\section{J. Clin. Invest.}

(c) The American Society for Clinical Investigation, Inc.

0021-9738/89/09/0773/08 \$2.00

Volume 84, September 1989, 773-780 extracellular proton excess impacts directly on isolated osteoclast-stimulated resorption (9). To analyze the mechanism by which protons regulate osteoclast activity, we exposed isolated osteoclasts to absolute and relative acid loads and queried if intracellular metabolism is altered. We found, in fact, that when exposed to extracellular protons, intraosteoclastic $\mathrm{pH}$ and $\mathrm{Ca}^{2+}$ levels rapidly decline, the latter mediated via an energy-dependent process. Most importantly, the changes in intracellular $\mathrm{pH}$ and calcium were associated with increased formation of podosomes. These are matrix-binding structures of osteoclasts localized at the level of the clear zone. They appear as short, microfilament-containing protrusions in contact with the substrate in which specific adhesion proteins are localized (10-12). Interestingly, podosomes also contain a $\mathrm{Ca}^{2+}$-regulated actin-severing protein, gelsolin (11), and specific receptors for arginine glycine aspartate (RGD) containing extracellular matrix proteins localized at the level of their plasma membrane (13). Thus, the results suggest that acidosis stimulates osteoclast attachment to bone, an early step in the resorptive process.

\section{Methods}

\section{Materials}

Fura 2-acetomethyl ester (Fura 2-AM), ${ }^{1}$ Fura 2-free acid, 2'7'-bis (2carboxyethyl)-5-carboxyfluorescein-tetracetoxymethyl ester (BCECFAM) and BCECF-free acid were purchased from Molecular Probes, Inc., Eugene, OR; mowiol and ionomycin from Calbiochem-Behring Corp., La Jolla, CA; all other agents were purchased from Sigma Chemical Co., St. Louis, MO.

\section{Osteoclast preparation}

Osteoclasts were isolated from the medullary bone of laying hens fed a calcium-deficient diet as previously described $(2,10,14) .10^{6}$ cells were plated with $100 \mu \mathrm{g}$ devitalized rat bone particles of $25-50-\mu \mathrm{m}$ diameter (15), in MEM + $10 \% \mathrm{FCS}, 100 \mu \mathrm{g} / \mathrm{ml}$ streptomycin, $100 \mathrm{IU} / \mathrm{ml}$ penicillin, $3 \mu \mathrm{g} / \mathrm{ml}$ cytosine 1B-D-arabinofuranoside (Ara-C), and cultured at $37^{\circ} \mathrm{C}$ in a water saturated atmosphere containing $5 \% \mathrm{CO}_{2}$. The bone particles were present throughout the isolation procedure, and osteoclasts remained attached to bone throughout the experiments. After 24 $\mathrm{h}$, the cells were recovered and sedimented twice for $20 \mathrm{~min}$ in PBS to allow osteoclasts, specifically bound to bone particles, to separate from lighter mononuclear bone marrow cells. The sediments were plated at a density of 50,000 osteoclasts in $3.5-\mathrm{cm}$ diameter petri dishes containing 25-mm-diam circle glass coverslips and cultured in MEM $+10 \%$ FCS, antibiotics, and Ara-C.

1. Abbreviations used in this paper: Ara-C, IB-D-arabinofuranoside; BCECF-AM, 2'7'-bis-(2-carboxyethyl)-5-carboxyfluorescein-tetracetoxy methyl ester; Btyr, butyric; Fura-2-AM, fura 2-acetomethyl ester; RGD, arginine glycine aspartate; R-PHD, rhodamine-conjugated phalloidin. 
Osteoclast $\mathrm{F}$ actin was localized in cells plated directly on coverslips without bone particles. This was necessary because the irregular surface of bone particles made avoidance of bone contributed autofluorescence impossible, preventing the techniques of visualizing $F$ actin in the podosomes on bone surfaces. For the glass coverslip cultures, cell suspensions obtained from the medullary bone were sedimented two to three times in $75 \%$ FCS and plated and after $24 \mathrm{~h}$ washed to remove nonadherent cells. Culture conditions were the same as described above. Since podosome formation is observed in osteoclasts attached to glass similar to bone laminae (12), these experiments were taken as resembling the effects seen in cells attached to bone. Additionally, in subsequent experiments on polished bone surfaces a similar appearance of podosome formation was observed and regulated by retinol (12).

\section{Measurement of intracellular $\mathrm{Ca}^{2+}$ and $\mathrm{pH}$}

(a) Fluorophore loading. Intracellular $\mathrm{pH}$ and intracellular calcium were measured in single cells using the fluorescent dyes BCECF and Fura-2, respectively. In their esterified forms, each dye diffuses into the cell where cytosolic esterases convert them into hydrophilic, impermeant-free acids. The conversion is rapid and prevents the dye from diffusing into the organelles, specifically allowing the measurements of cytosolic $\mathrm{pH}$ and $\left[\mathrm{Ca}^{2+}\right]_{\mathrm{i}}$. Both dyes were dissolved in DMSO, which had no effect in any experimental situation.

Osteoclasts, cultured on coverslips, were incubated for $1 \mathrm{~h}$ at $37^{\circ} \mathrm{C}$ in a buffer containing $125 \mathrm{mM} \mathrm{NaCl}, 5 \mathrm{mM} \mathrm{KCl}, 1.2 \mathrm{mM} \mathrm{KH}_{2} \mathrm{PO}_{4}$, $1.2 \mathrm{mM} \mathrm{MgSO}_{4}, 2 \mathrm{mM} \mathrm{CaCl}_{2}, 25 \mathrm{mM}$ Hepes, $6 \mathrm{mM}$ glucose (PBS, Table I), and $10 \mu \mathrm{M}$ fura-2-AM or $10 \mu \mathrm{M}$ BCECF-AM. The cells were then washed three times in PBS to remove extracellular dye. Fluorescence was measured in single cells excited with light at appropriate wavelengths selected by monochromators and directed through the stage of a Nikon inverted microscope equipped with a $100 \times$ fluor objective. The cells attached to bone were large enough such that the area of the cell immediately adjacent to the bone was excluded from the field. This allowed us to avoid some of the high levels of background fluorescence contributed by bone particles. However, background fluorescence was measured in all experiments and subtracted from the experimental recordings. Light emitted from the cells was monitored photometrically (Spex Industries, Edison, NJ). Real-time recordings of fluorescence were obtained at two excitation wavelengths.

(b) Intracellular calcium. The $\mathrm{Ca}^{2+}$-dependent fluorescence of intracellular Fura-2 was measured at excitation wavelengths of 340 and $380 \mathrm{~nm}$ and an emission wavelength of $505 \mathrm{~nm}$. Moreover, Fura-2 fluorescence was calibrated to $\left[\mathrm{Ca}^{2+}\right]_{\mathrm{i}}$ at the end of each experiment. To this end, the cells were exposed to $5 \mu \mathrm{M}$ ionomycin to assess Ca-saturated fluorescence $\left(F_{\max }\right)$, followed by $5 \mathrm{mM}$ EGTA to determine Fura-2 fluorescence at a Ca concentration of $0 \mathrm{nM}\left(F_{\min }\right) .2 \mathrm{mM}$ $\mathrm{MnCl}_{2}$ was finally added to estimate Ca-independent nonspecific fluorescence (autofluorescence) which was subtracted from the excitation wavelengths taken at 340 and $380 \mathrm{~nm}$. The ratio between the fluorescence at these two wavelengths was calculated and $\left[\mathrm{Ca}^{2+}\right]_{i}$ determined using the formula published by Grynkiewicz et al. (16). (c) Intracellular $p H$. BCECF fluorescence was monitored at excitation wavelengths 495 (pH sensitive) and 440 (isosbestic point) $\mathrm{nm}$ with an emission wavelength of $505 \mathrm{~nm}$. Autofluorescence was measured for $30 \mathrm{~s}$ (before loading with fluorescent dye) and subtracted from the experimental values. $\mathrm{pH}_{\mathrm{i}}$ was calculated from calibration curves constructed at the end of each experiment by treating the cell with $4 \mu \mathrm{M}$ nigericin $\left(\mathrm{K}^{+} / \mathrm{H}^{+}\right.$ionophore) in a buffer containing $130 \mathrm{mM}$ $\mathrm{KCl}, 20 \mathrm{mM} \mathrm{NaCl}, 5 \mathrm{mM}$ Hepes at known pHs ranging from 6.5 to 7.5 .

(d) Effect of pH on fura-2 fluorescence. The excitation spectrum of $1 \mu \mathrm{M}$ Fura- 2 free acid was recorded in $135 \mathrm{mM} \mathrm{KCl}, 5 \mathrm{mM}$ Hepes with or without $2 \mathrm{mM}$ EGTA, at $37^{\circ} \mathrm{C}$. Using EGTA-containing buffers, excitation spectra were developed as described by Grynkiewicz et al. (16). Alternately, distilled water containing $200 \mu \mathrm{M}$ ionized calcium was added to EGTA-free buffer, the $\mathrm{pH}$ was adjusted to $6.5,7.05,7.4$, and 7.6 with $\mathrm{KOH}$, and the spectra were recorded.

(e) Effect of membrane depolarization on $\mathrm{pH}_{i}$ and $\left[\mathrm{Ca}^{2+}\right]_{i}$. The effect of membrane depolarization was studied in both BCECF- and Fura-2-loaded osteoclasts, substituting PBS with a buffer containing $130 \mathrm{mM} \mathrm{KCl}, 20 \mathrm{mM} \mathrm{NaCl}, 2 \mathrm{mM} \mathrm{CaCl}$, 5 mM Hepes, pH 7.4 (high $\mathrm{K}^{+}$, Table I). The added impact of extracellular acidification was assessed in cells treated with the same buffer at $\mathrm{pH}$ 5.3. The influence of extracellular $\mathrm{Na}^{+}$was also evaluated using a Na${ }^{+}$-free/high- $\mathrm{K}^{+}$buffer (150 mM KCl, $2 \mathrm{mM} \mathrm{CaCl}_{2}, 5 \mathrm{mM}$ Hepes, $\mathrm{pH} 7.4$ ).

$(f)$ Podosome expression. Expression of these adhesion structures in osteoclast clear zones was studied using rhodamine-conjugated phalloidin (R-PHD) which specifically binds $F$ actin (17). The cells under study were cultured in absence of bone particles in basal conditions, or treated for $15,30,60$, and 90 min as follows: $(i)$ Controls incubated in serum-free MEM/Hepes, $\mathrm{pH} 7.4$; (ii) Osteoclasts acidified with MEM/Hepes + $25 \mathrm{mM} \mathrm{NaBtyr}$, pH 7.0; (iii) Osteoclasts alkalinized with MEM/Hepes $+25 \mathrm{mM} \mathrm{NaHCO}$, pH 7.6 and then acidified by removal of $\mathrm{HCO}_{3}^{-}, \mathrm{pH} 7.4$; (iv) Osteoclasts acidified with MEM/Hepes $+25 \mathrm{mM} \mathrm{NaBtyr}$ in presence of $2.5 \mathrm{mM} \mathrm{NaCN}$ or 0.5 $\mathrm{mM} \mathrm{Na}_{3} \mathrm{VO}_{4} .25 \mathrm{mM} \mathrm{NaCl}$ was added to control medium to assure isoosmolarity with experimental conditions. The cells were fixed for 5 min at room temperature in PBS, $2 \%$ sucrose, $3 \%$ paraformaldehyde at the desired $\mathrm{pH}(7.0,7.4$, or 7.6), washed in PBS, permeabilized in 20 $\mathrm{mM}$ Hepes (pH 7.4), $300 \mathrm{mM}$ sucrose, $50 \mathrm{mM} \mathrm{NaCl}, 3 \mathrm{mM} \mathrm{MgCl}$, $0.5 \%$ Triton $\mathrm{X}-100$, for $3 \mathrm{~min}$ at $0^{\circ} \mathrm{C}$, and again washed in PBS. The cells were then incubated with $10 \mu \mathrm{g} / \mathrm{ml} \mathrm{R}$-PHD for $45 \mathrm{~min}$ at $37^{\circ} \mathrm{C}$. The coverslips were washed in PBS, mounted with $10 \%$ mowiol (vol/ vol), and placed in a Leitz Diavert microscope equipped for epifluorescence. In each circumstance, the number of osteoclasts exhibiting or free of podosomes was counted (not less than 300 cells/treatment), and the percentage of each was calculated. Results were expressed as mean percentage $\pm S E$ of podosome-containing osteoclasts vs. time. Statistical significance was evaluated by $t$ test, and each experiment was performed at least three times.

\section{Results}

Intracellular $p H$. Basal $\mathrm{pH}_{\mathrm{i}}$, namely that of cells incubated with bone in PBS ( $\mathrm{pH} 7.4$ ) was measured at the beginning of

Table I. Composition of the Various Buffers Used

\begin{tabular}{|c|c|c|c|c|c|c|c|c|c|c|}
\hline Buffer & $\mathrm{NaCl}$ & $\mathrm{NaHCO}_{3}$ & NaBtyr & $\mathrm{KCl}$ & $\mathrm{KH}_{2} \mathrm{PO}_{4}$ & $\mathrm{MgSO}_{4}$ & $\mathrm{CaCl}_{2}$ & Glucose & Hepes & pH \\
\hline & \multicolumn{10}{|c|}{$m M$} \\
\hline PBS & 125 & 0 & 0 & 5 & 1.2 & 1.2 & 2 & 6 & 25 & 7.4 \\
\hline NaBtyr & 100 & 0 & 25 & 5 & 1.2 & 1.2 & 2 & 6 & 25 & 7.0 \\
\hline $\mathrm{HCO}_{3}^{-}$ & 100 & 25 & 0 & 5 & 1.2 & 1.2 & 2 & 6 & 25 & 7.6 \\
\hline High K & 20 & 0 & 0 & 130 & 1.2 & 1.2 & 2 & 6 & 25 & 7.4 \\
\hline High K NaBtyr & 0 & 0 & 25 & 125 & 1.2 & 1.2 & 2 & 6 & 25 & 7.0 \\
\hline
\end{tabular}

Constituent concentrations are in millimolars. 
each experiment. Thus, intraosteoclast $\mathrm{pH}$ was $7.08 \pm 0.01$ ( $n$ $=25$ ), and it was stable in this condition for at least $1 \mathrm{~h}$, or longer than the experimental duration. Osteoclast cytosol was acidified by either exposure to metabolic acid or $\mathrm{HCO}_{3}^{-}$withdrawal (Fig. 1). In the first circumstance, the cells were incubated in a buffer containing $25 \mathrm{mM} \mathrm{NaBtyr}$ (NaBtyr buffer, Table I) isotonically substituted for $\mathrm{NaCl}$ at $\mathrm{pH} 7.0$ leading to generation of $79 \mu \mathrm{M}$ butyric acid. NaBtyr additionally lowered $\mathrm{pH}_{\mathrm{i}}$ to $6.56 \pm 0.20\left(\Delta \mathrm{pH}_{\mathrm{i}}=-0.60\right.$, Table II) within $10 \mathrm{~s}$ of exposure (Fig. 1, $A$ and $B$ ).

Alternatively, osteoclasts were exposed to a buffer containing $25 \mathrm{mM} \mathrm{NaHCO}_{3}$, isotonically substituted for $\mathrm{NaCl}\left(\mathrm{HCO}_{3}^{-}\right.$ buffer, $\mathrm{pH}$ 7.6, Table I), which, within $20 \mathrm{~min}$, raised $\mathrm{pH}_{\mathrm{i}}$ to $7.60 \pm 0.05\left(\Delta \mathrm{pH}_{\mathrm{i}}=0.55\right.$, Table II $)$. Replacement of the medium by $\mathrm{PBS}$ at this time prompted $\mathrm{HCO}_{3}^{-}$efflux, and return to basal $\mathrm{pH}_{\mathrm{i}}\left(\mathrm{pH}_{\mathrm{i}} 7.0 \pm 0.10, \Delta \mathrm{pH}_{\mathrm{i}}=-0.48\right.$; Fig. 1, $C$ and $\left.D\right)$. These results differ from experiments in other cells, where reduction of $\mathrm{HCO}_{3}^{-}$in the media produces a transient alkalinization before return to basal $\mathrm{pH}$. In our experiments, $\mathrm{CO}_{2}$ was not controlled and the cells were $\mathrm{HCO}_{3}^{-}$loaded. These differences account for the observed results. The reduction in $\mathrm{pH}_{\mathrm{i}}$ was due to the operation of $\mathrm{Cl}^{-} / \mathrm{HCO}_{3}^{-}$exchange mechanism (15), since the reduction in $\mathrm{pH}_{\mathrm{i}}$ was $\mathrm{Cl}^{-}$dependent and 4,4'diisothiocyano-2,2'-stilbene sulfonic acid inhibitable. The relative rate of intracellular acidification after sequential $\mathrm{HCO}_{3}^{-}$ loading and withdrawal was much slower than that induced by butyric acid. Experiments similar to that shown in Fig. 1 and all subsequent figures were repeated numerous times on separate coverslips, as indicated in Table II or in the text.

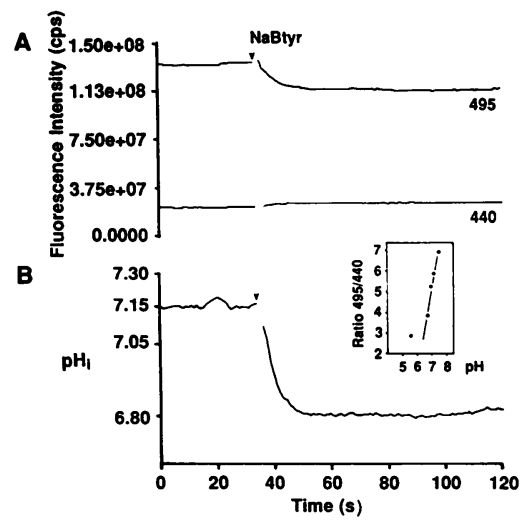

Figure 1. Effects of butyric acid and bicarbonate removal on $\mathrm{pH}_{\mathrm{i}}$. $(A$ and $B$ ) Osteoclasts in control buffer loaded with BCECF were studied while the PBS buffer was changed to one containing $25 \mathrm{mM}$ NaBtyr. Intracellular $\mathrm{pH}$ was determined at the end of the experiments by cell membrane permeabilization with nigericin in buffers containing $130 \mathrm{mM}$ $\mathrm{KCl}$ at various $\mathrm{pH}_{\mathrm{i}} .(A)$ Real time recording of BCECF fluorescence at excitation wavelengths $495 \mathrm{~nm}$ (pH dependent), and $440 \mathrm{~nm}$ (isosbestic) NaBtyr addition rapidly decreased cell fluorescence when they were excited at 495 $\mathrm{nM}$, whereas fluores-

cence at $440 \mathrm{nM}$ excitation remained stable, indicating a fall in $\mathrm{pH}_{\mathrm{i}}$. $(B)$ When the real time recording was transformed to a ratio, and calibrated to $\mathrm{pH}_{\mathrm{i}}$ by the curve in the inset, the magnitude of the $\mathrm{pH}_{\mathrm{i}}$ drop was apparent. ( $C$ and $D$ ) osteoclasts maintained in $\mathrm{HCO}_{3}^{-}$ buffer for $25 \mathrm{~min}$ were observed during subsequent incubation in PBS. (C) Real time recording of BCECF fluorescence at $495 \mathrm{~nm}$ and $440 \mathrm{~nm}$ as in A. (D) Ratios of data in $C$ calibrated to $\mathrm{pH}_{\mathrm{i}}$.
Intracellular $\mathrm{Ca}^{2+}$. Basal $\left[\mathrm{Ca}^{2+}\right]_{\mathrm{i}}$ measured in PBS was $132 \pm 40 \mathrm{nM}(n=25)$ which remained stable for $60 \mathrm{~min}$. When osteoclasts were acidified with $\mathrm{NaBtyr},\left[\mathrm{Ca}^{2+}\right]_{\mathrm{i}}$ rapidly fell to $56 \pm 9 \mathrm{nM}\left(\Delta\left[\mathrm{Ca}^{2+}\right]_{\mathrm{i}}=-58 \mathrm{nM}\right.$, Fig. $2, A$ and $B$, Table II). Alternatively, $\mathrm{HCO}_{3}^{-}$-induced alkalinization increased $\left[\mathrm{Ca}^{2+}\right]_{\mathrm{i}}$ to $225 \pm 37 \mathrm{nM}\left(\Delta\left[\mathrm{Ca}^{2+}\right]_{\mathrm{i}}=80 \mathrm{nM}\right.$, Fig. $2, C$ and $D$, Table II $)$ and subsequent incubation of the cells in PBS prompted a rapid decrease in the intracellular cation to $110 \mathrm{nM}\left(\Delta\left[\mathrm{Ca}^{2+}\right]_{\mathrm{i}}\right.$ $=97 \mathrm{nM}$; Fig. 2, $C$ and $D$ ). Interestingly, $\mathrm{HCO}_{3}^{-}$removal changed $\left[\mathrm{Ca}^{2+}\right]_{i}$ more rapidly than $\mathrm{pH}_{\mathrm{i}}$, and was comparable to NaBtyr treatment.

Effect of $p H$ on Fura-2 fluorescence. No alteration of the excitation spectra of Fura-2 fluorescence occurred by $\mathrm{pH}$ modification whether studied in the presence or absence of EGTA (not shown). Thus, direct effects of protons on Fura-2 fluorescence could not account for the changes in $\left[\mathrm{Ca}^{2+}\right]_{i}$ documented in Fig. 2 and Table II.

Osteoclast acidification in $\mathrm{Na}^{+}$-free buffer. These experiments were designed to determine if the acid-induced fall in $\left[\mathrm{Ca}^{2+}\right]_{\mathrm{i}}$ was $\mathrm{Na}^{+}$dependent. To this end, $N$-methylglucamine and butyric acid were isotonically substituted for the Na-containing constituents of the NaBtyr buffer. The $\mathrm{pH}$ and, thus, the butyric acid concentration was similar to the Na-containing buffer. Addition of the sodium-free/butyrate buffer prompted a rapid decrease in $\left[\mathrm{Ca}^{2+}\right]_{i}$ similar to the Na-containing buffer. In addition, ouabain, $10^{-4} \mathrm{M}$, had no inhibitory effect on NaBtyr-induced reduction in $\left[\mathrm{Ca}^{2+}\right]_{i}$. Thus, the fall in $\left[\mathrm{Ca}^{2+}\right]_{\mathrm{i}}$ produced by $\mathrm{NaBtyr}$ does not reflect activity of the $\mathrm{Na}^{+} / \mathrm{Ca}^{2+}$ exchange mechanism.

Effect of membrane depolarization on osteoclast $\mathrm{pH}_{i}$ and $\left[\mathrm{Ca}^{2+}\right]_{i}$. High potassium-induced membrane depolarization caused slow cytosolic alkalinization to $\mathrm{pH} 7.51\left(\mathrm{pH}_{\mathrm{i}}=0.47\right)$, and a rapid decrease in $\left[\mathrm{Ca}^{2+}\right]_{\mathrm{i}}$ to $95 \mathrm{nM}$, which was complete within $20 \mathrm{~s}$ (Fig. 3). This effect was reversible and basal $\left[\mathrm{Ca}^{2+}\right]_{i}$ levels reappeared after removal of the high potassium buffer (Fig. 3). The impact of membrane depolarization on $\left[\mathrm{Ca}^{2+}\right]_{i}$ was also independent of extracellular sodium as it was unaffected by a Na-free, high-K buffer (data not shown). Alternatively, reduction of the high- $\mathrm{K}^{+}$buffer $\mathrm{pH}$ to 5.3 enhanced the depolarization-induced decline in $\left[\mathrm{Ca}^{2+}\right]_{\mathrm{i}}$ to $35 \mathrm{nM}$, an event that was also $\mathrm{Na}$ independent (Fig. 3). This indicates that the affect of depolarization was additive to that of protons. Thus, the osteoclast appears to possess either a means of $\mathrm{Ca}^{2+}$ efflux that is electrogenic and thus stimulated by depolarization or, the capacity to sequester $\mathrm{Ca}^{2+}$ intracellularly in response to protons and/or depolarization.

Effect of $\mathrm{NaCN}$ and $\mathrm{Na}_{3} \mathrm{VO}_{4}$ on osteoclast $\mathrm{pH}_{i}$ and $\left[\mathrm{Ca}^{2+}\right]_{i}$. These experiments were designed to determine if acid-regulated change in $\left[\mathrm{Ca}^{2+}\right]_{i}$ was ATP-dependent and related to the transport action of a plasma membrane Ca-ATPase. In this regard, we used $0.5 \mu \mathrm{M}$ of the $\mathrm{Ca}^{2+}$ ATPase inhibitor, $\mathrm{Na}_{3} \mathrm{VO}_{4}$ (18), or $2.5 \mathrm{mM}$ of the ATP synthesis blocker, $\mathrm{NaCN}$.

Our initial experiments documented that $\mathrm{NaCN}$ increased fluorescence of BCECF-free acid. Similarly, we found that cyanide led to enhanced intraosteoclast fluorescence of the $\mathrm{pH}$ sensitive dye (Fig. $4 A$ ), an effect considered when calculating $\mathrm{pH}_{\mathrm{i}}$ (Fig. $4 \mathrm{~B}$ ). When added to the NaBtyr-containing buffer, neither $\mathrm{CN}^{-}$or $\mathrm{VO}_{4}^{3-}$ blocked intracellular acidification (Fig. 4) but both reduced the initial rate of associated $\left[\mathrm{Ca}^{2+}\right]_{i}$ decline (Figs. 5 and $6 \mathrm{~A}$ ). At this juncture, the data indicated that protons stimulated cytosolic acidification and a reduction in cytosolic calcium, possibly through stimulation of a plasma 
Table II. Mean $\left[\mathrm{Ca}^{2+}\right]$ and $\mathrm{pH}_{i}$ during Various Experimental Conditions Displayed in Figs. 1-7

\begin{tabular}{lcccc}
\hline & \multicolumn{3}{c}{$\mathrm{NaBtyr}$} & \multicolumn{2}{c}{$\mathrm{NaHCO}_{3}$} & Experimental \\
\cline { 2 - 5 } & Basal & Experimental & $145 \pm 26$ & $225 \pm 37^{\ddagger}$ \\
\hline$\left[\mathrm{Ca}^{2+}\right]_{\mathrm{i}}(n M)$ & $114 \pm 18$ & $56 \pm 9^{*}$ & -58 & 80 \\
$\Delta\left[\mathrm{Ca}^{2+}\right]_{\mathrm{i}}(n m)$ & & $6.56 \pm 0.20^{*}$ & & $7.60 \pm 0.05^{\ddagger}$ \\
$\mathrm{pH}_{\mathrm{i}}$ & $7.16 \pm 0.10$ & -0.60 & & 0.55 \\
$\Delta \mathrm{pH}_{\mathrm{i}}$ & & & & \\
\hline
\end{tabular}

Data in the table are mean \pm SEM. ${ }^{*} P<0.01, n=4 ;{ }^{\ddagger} P<0.03, n=6$ by paired $t$ test.

membrane Ca-ATPase. Because both of these alterations in cytosolic milieu have been shown to affect cytoskeletal organization, we next turned our attention to microfilaments of the osteoclast and their organization into a unique adhesion structure, the podosomes.

Effect of altered $\mathrm{pH}_{\mathrm{i}}$ on osteoclast podosome formation. $43 \%$ of osteoclasts, maintained in control culture conditions for $2 \mathrm{~d}$, developed podosomes, whereas in the remaining cells, $F$ actin was distributed in membrane ruffles or a fine network (Table III, Fig. 7, $A$ and $B$ ). The change to serum-free MEM/ Hepes, mimicking the experimental conditions for $\mathrm{pH}_{\mathrm{i}}$ and $\left[\mathrm{Ca}^{2+}\right]_{\mathrm{i}}$ determinations, prompted a transient fall in podosome presentation but a return to initial values occurred within 30-60 min (Fig. $8 \mathrm{~A}$ ). NaBtyr treatment, however, led to a less pronounced decline in the percentage of osteoclasts demonstrating attachment structures that by $90 \mathrm{~min}$ rose to $73 \%$, a $73 \%$ increase over control (Fig. $8 \mathrm{~A}$ ). In some experiments, the

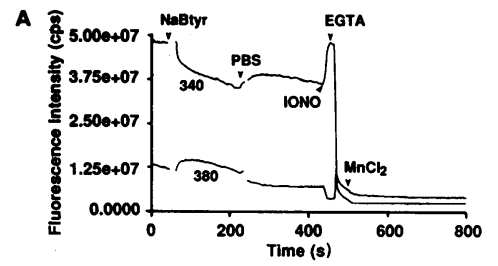

Figure 2. Effects of butyric acid and bicarbonate removal on $\left[\mathrm{Ca}^{2+}\right]_{\mathrm{i}}$. $(A$ and $B)\left[\mathrm{Ca}^{2+}\right]_{\mathrm{i}}$ in osteoclasts treated with $\mathrm{NaBtyr}$. Addition of NaBtyr promptly reduced $\left[\mathrm{Ca}^{2+}\right]_{i}$, and acid

B
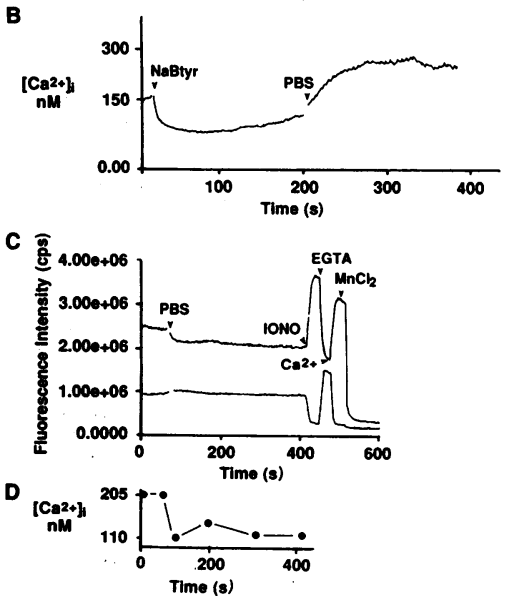
removal (PBS) reversed the effect. Ratio recordings of Fura-2 fluorescence were calibrated using ionomycin to obtain maximal $\mathrm{Ca}^{2+}$-dependent fluorescence and EGTA for minimal $\mathrm{Ca}^{2+}$-dependent fluorescence. Background fluorescence was determined by obliteration of $\mathrm{Ca}^{2+}$-dependent fluorescence with $1 \mathrm{mM}$ $\mathrm{MnCl}_{2}$. (A) Real-time recording of Fura-2 fluorescence excited at 340 $\mathrm{nm}$ and $380 \mathrm{~nm}$. (B)

Ratio recording of data in $A$ calibrated to $\left[\mathrm{Ca}^{2+}\right]_{\mathrm{i}}$. Addition of $\mathrm{NaB}-$ tyr promptly reduced $\left[\mathrm{Ca}^{2+}\right]_{\mathrm{i}}$, and acid removal (PBS) reversed the effect. $(C$ and $D$ ) osteoclasts preincubated in the bicarbonate-containing buffer were studied during the change to PBS. Change to bicarbonate free buffer was associated with a prompt decline in $\left[\mathrm{Ca}^{2+}\right]_{\mathrm{i}}$. (C) Real-time recording of Fura-2 fluorescence as in $A$. (D) Ratios of data in $\mathrm{C}$ calibrated to $\left[\mathrm{Ca}^{2+}\right]_{\mathrm{i}}$. presence of $\mathrm{NaBtyr}$ initial transient fall in podosomes was not observed (Fig. 9). The podosomes, in this circumstance, are generally organized in a layered peripheral ring resembling the clear zone (Fig. 7, $C$ and $D$ ).

Acidification by $\mathrm{HCO}_{3}^{-}$removal. Transfer of cells to the $\mathrm{HCO}_{3}^{-}$buffer reduced podosome formation, but in contrast to PBS, the attachment structures did not redevelop, appearing in only $7 \%$ of the resorptive cells after 90 min (Fig. $8 \mathrm{~B}$ ). Interestingly, $\mathrm{HCO}_{3}^{-}$-loaded cells assume a globular shape and $F$ actin is largely confined to membrane ruffles. Removal of $\mathrm{HCO}_{3}^{-}$reversed these events, and control levels of podosome expression reappeared (Fig. $8 \mathrm{~B}$ ) correlating well with the return of $\mathrm{pH}_{\mathrm{i}}$ to control levels as discussed above (Fig. 1).

Effect of $\mathrm{Na}_{3} \mathrm{VO}_{4}$ and $\mathrm{Na} \mathrm{CN}$ on osteoclast podosomes. Exposure of osteoclasts to $0.5 \mu \mathrm{M} \mathrm{Na} \mathrm{NO}_{4}$ totally blocked podosome formation (Fig. 9) and $2.5 \mathrm{mM} \mathrm{KCN}$ reduced the percentage of positive cells to 14.9 (Table III). Addition of $\mathrm{Na}_{3} \mathrm{VO}_{4}$ to the $\mathrm{NaBtyr}$ buffer also led to a pronounced, albeit incomplete inhibition of podosome formation (Fig. 9). $\mathrm{NaCN}$ added to the $\mathrm{NaBtyr}$ buffer produced effects similar to $\mathrm{Na}_{3} \mathrm{VO}_{4}$ (Table III).

Effect of ionomycin on podosome formation. We used a $\mathrm{Ca}^{2+}$ ionophore to test the hypothesis that $\mathrm{Ca}^{2+}$ per se affected

A

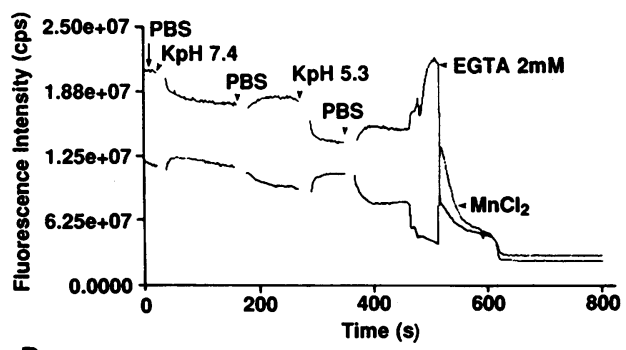

B

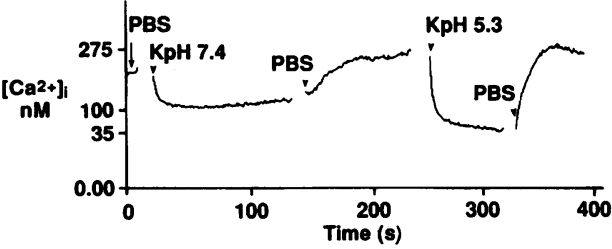

Figure 3. Effect of depolarization by $\mathrm{KCl}$ on $\left[\mathrm{Ca}^{2+}\right]_{i}$. An osteoclast was incubated in high-K (Table I) buffer and Fura-2 fluorescence was recorded. Substitution of PBS with high-K buffer induced a rapid and reversible decrease in $\left[\mathrm{Ca}^{2+}\right]_{\mathrm{i}}$. High-K buffer at $\mathrm{pH} 5.3$ stimulated an even greater fall in $\left[\mathrm{Ca}^{2+}\right]_{\mathrm{i}} .(A)$ Real-time recording of fura-2 at excitation $340 \mathrm{nM}(t o p)$ and $380 \mathrm{nM}$ (bottom). (B) Calibration of Fura-2 fluorescence into $\left[\mathrm{Ca}^{2+}\right]_{\mathrm{i}}$. 
A

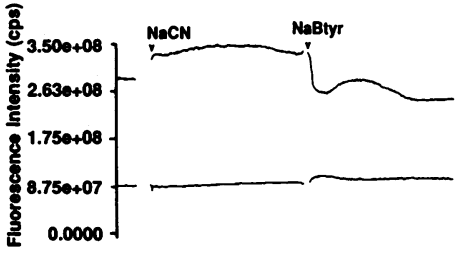

B
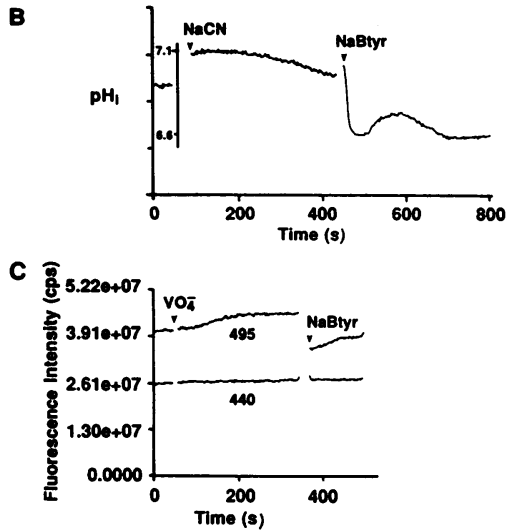

Figure 4. Effect of $\mathrm{NaCN}$ and $\mathrm{Na}_{3} \mathrm{VO}_{4}$ on butyric acid-stimulated acidification. $(A$ and $B)$ osteoclasts in PBS buffer were observed during addition of 2.5 $\mathrm{mM} \mathrm{NaCN}$. $\mathrm{NaCN}$ increased BCECF fluorescence at 495 excitation and to a lesser degree, $440 \mathrm{~nm}$ excitation. Calibration of BCECF fluorescence was adjusted for the $\mathrm{NaCN}$ effect $(B)$ $\mathrm{NaCN}$ produced a slow cytoplasmic acidification but did not alter the effect of NaBtyr. (C) An osteoclast was observed during a change from PBS to one containing $0.5 \mu \mathrm{M}$ $\mathrm{Na}_{3} \mathrm{VO}_{4}$. As with $\mathrm{CN}_{3}^{-}$, $\mathrm{VO}_{4}^{3-}$ did not affect the rapid reduction in pHi produced by $\mathrm{NaBtyr}$ addition.

podosome formation. We found that exposure of osteoclasts to low doses $\left(10^{-8} \mathrm{M}\right)$ of ionomycin led to a transient increase (1-2 $\mathrm{min}$ ) and a sustained approximate doubling of $\left[\mathrm{Ca}^{2+}\right]_{i}$. Podosome formation was reduced by ionomycin treatment (Table III). Although we cannot exclude that this effect was due to toxicity of ionomycin, at this low-dose cell morphology was unaffected, and the increase in $\left[\mathrm{Ca}^{2+}\right]_{i}$ was transient with a return to levels $\sim 1.5-2$ times basal after 1-2 min. The ability of the osteoclast to return $\left[\mathrm{Ca}^{2+}\right]_{i}$ levels towards normal for prolonged periods indicates sufficient energy production by the cell to maintain cell $\mathrm{Ca}^{2+}$ efflux and compartmentation. We took this as good evidence for maintenance of cell viability. Thus, podosome development appeared inversely related to $\left[\mathrm{Ca}^{2+}\right]_{i}$, and enhancement or reduction of attachment structure formation by metabolic acid, and inhibitors may reflect, in part, their respective effects on cytosolic calcium.

\section{Discussion}

The osteoclast is a cell whose principal activity depends upon proton transport. Thus, the pivotal event in bone degradation is the secretion of $\mathrm{H}^{+}$ions by resorptive cells into an isolated, extracellular microenvironment at the osteoclast-matrix attachment site $(1,19)$. The $\mathrm{H}^{+}$ATPase responsible for acidification of the resorptive microenvironment has been shown to be a vacuolar $\mathrm{H}^{+}$-ATPase, functionally similar to the renal $\mathrm{H}^{+}$ATPase responsible for urinary acidification (19).

The osteoclast is also known to respond, in the complicated milieu of whole animal or organ culture models, to extracellular proton excess. For example, metabolic acidosis is associated with skeletal loss, and bone rudiments cultured at low pH undergo enhanced resorption (5-8). In addition, Arnett and Dempster have shown that low pH stimulated isolated osteoclasts to increase bone resorption (9). However, whether the effect of acidosis is mediated by a direct $\mathrm{pH}$ effect on bone mineral- or osteoclast-mediated resorption remains
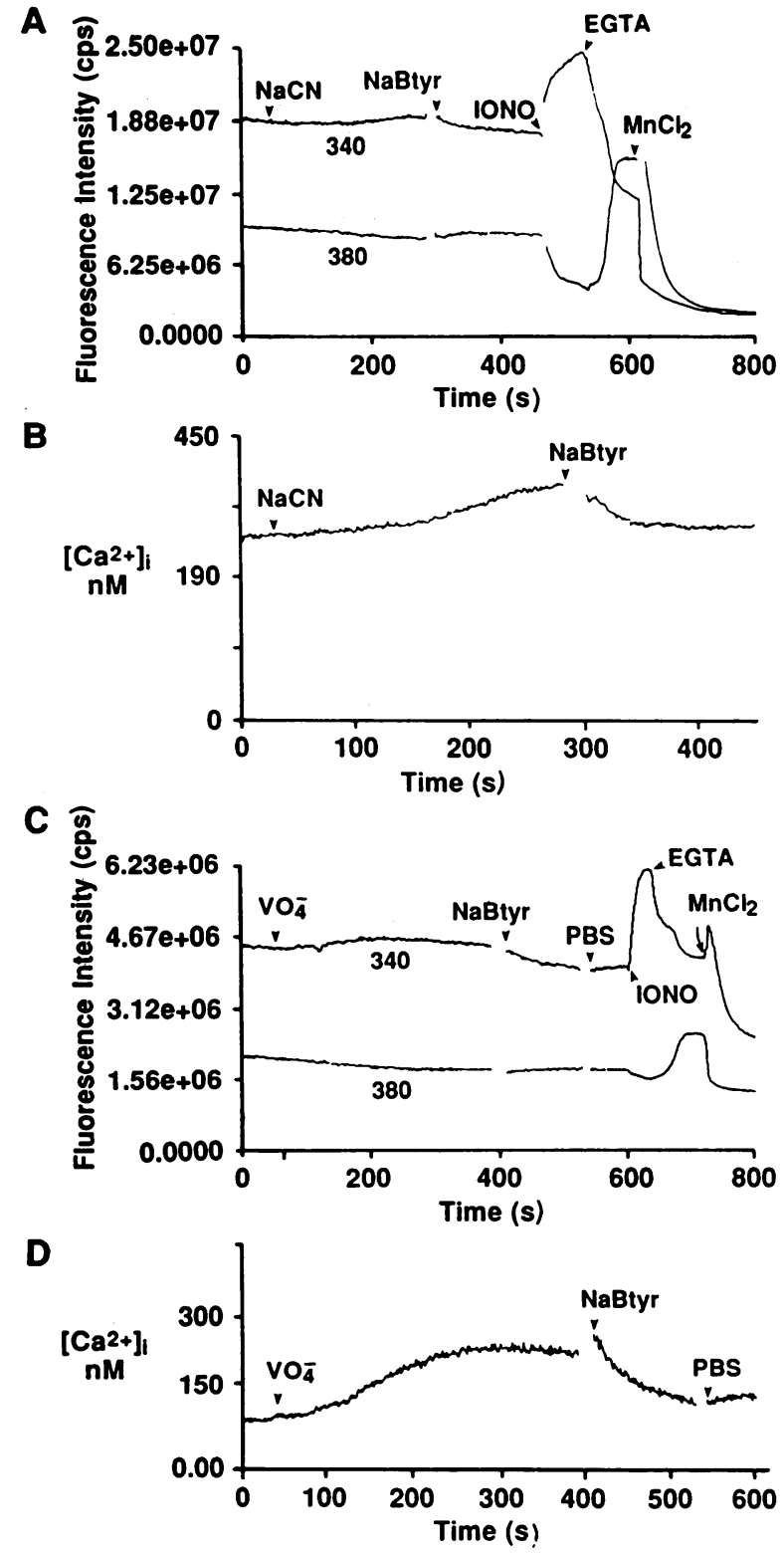

Figure 5. Effect of cyanide and vanadate on butyric acid-stimulated $\mathrm{Ca}^{2+}$ efflux. $(A$ and $B$ ) Cyanide and vanadate addition of buffer containing $2.5 \mathrm{mM} \mathrm{NaCN}$ produced a slow increase in $\left[\mathrm{Ca}^{2+}\right]_{i}$ and blunted the effect of NaBtyr on $\left[\mathrm{Ca}^{2+}\right]_{i}$. $(C$ and $D$ ) Additions of 0.5 $\mathrm{nM} \mathrm{Na} \mathrm{VO}_{4}$ also increased $\left[\mathrm{Ca}^{2+}\right]_{\mathrm{i}}$ and blunted the effect of $\mathrm{NaBtyr}$ addition. $(A$ and $C$ ) Real time Fura-2 recordings at 340 and $380 \mathrm{~nm}$. $(B$ and $D)$ Ratio recording of the Fura-2 signal calibrated to $\left[\mathrm{Ca}^{2+}\right]_{\mathrm{i}}$.

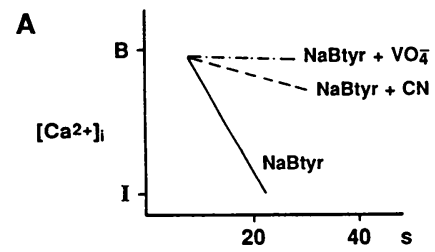

B

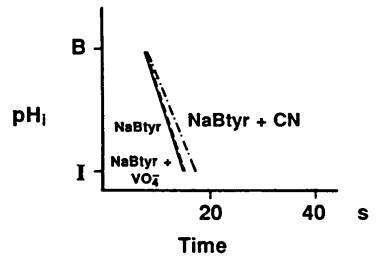

Figure 6. Effects of cyanide and vanadate inhibitors on the initial rate of butyric acid stimulated $\mathrm{Ca}^{2+}$ efflux and acidification. Vanadate and cyanide inhibited the reduction of $\left[\mathrm{Ca}^{2+}\right]_{i}$ stimulated by $\mathrm{NaBtyr}$ but did not affect the change in $\mathrm{pH}_{\mathrm{i}}$ produced by the metabolic acid. Data are the mean of the initial rates of five experiments. 
Table III. Percentage \pm SE of Osteoclasts Exhibiting Podosomes after 90 min of Treatment

\begin{tabular}{lcc}
\hline \multicolumn{1}{c}{ Treatment } & $\mathrm{pH}$ of the medium & Percentage \\
\hline Control & 7.4 & $42.55 \pm 0.73$ \\
$\mathrm{NaBtyr}$ & 7.0 & $73.68 \pm 0.81^{*}$ \\
$\mathrm{HCO}_{3}^{-}$ & 7.6 & $7.11 \pm 0.67^{*}$ \\
$\mathrm{HCO}_{3}^{-} /$control & $7.6 / 7.4$ & $42.07 \pm 3.55^{\ddagger}$ \\
$\mathrm{Control}+\mathrm{VO}_{4}$ & 7.4 & $1.96 \pm 0.01^{\ddagger}$ \\
Control $+\mathrm{CN}^{-}$ & 7.4 & $14.9 \pm 1.17$ \\
$\mathrm{NaBtyr}+\mathrm{VO}_{4}$ & 7.0 & $28.54 \pm 2.29^{\S}$ \\
$\mathrm{NaBtyr}+\mathrm{CN}^{-}$ & 7.0 & $18.5 \pm 0.18$ \\
lonomycin & 7.4 & $25.98 \pm 0.17^{*}$ \\
\hline
\end{tabular}

MEM $+25 \mathrm{mM}$ Hepes. Data are mean \pm SE.

${ }^{*} P<0.001$ with respect to control;

${ }^{\ddagger} \mathrm{NS}$ with respect to control;

${ }^{\S} P<0.001$ with respect to $\mathrm{NaBtyr}$ treated in the absence of $\mathrm{VO}_{4}$.

controversial (20). In addition, the mechanism of proton action was not studied by Arnett and Dempster.

We have developed means by which osteoclasts may be isolated and individual cells studied in culture enabling one to determine if they directly respond to specific agonists $(2,14)$. Thus, we found that $\mathrm{pH}_{\mathrm{i}}$ was altered by extracellular proton manipulation via a metabolic acid load or $\mathrm{HCO}_{3}^{-}$removal. Furthermore, alterations of $\mathrm{pH}_{\mathrm{i}}$ prompted a corresponding change in $\left[\mathrm{Ca}^{2+}\right]_{i}$. Thus, increases in protons appeared to stimulate $\mathrm{Ca}^{2+}$ efflux via a Ca-ATPase producing a reduction in $\left[\mathrm{Ca}^{2+}\right]_{i}$. The fall in $\left[\mathrm{Ca}^{2+}\right]_{\mathrm{i}}$ was rapid and prolonged, occurring within $15 \mathrm{~s}$ of exposure and persisting for at least $20 \mathrm{~min}$. As expected, intracellular alkalinization, induced by $\mathrm{HCO}_{3}^{-}$loading, had an effect opposite to that of acidosis, namely enhancement of both $\mathrm{pH}_{\mathrm{i}}$ and $\left[\mathrm{Ca}^{2+}\right]_{i}$.

Our data suggest that transmembrane efflux other than by $\mathrm{Na}^{+} / \mathrm{Ca}^{2+}$ exchange, may be the means by which acidification reduces $\left[\mathrm{Ca}^{2+}\right]_{i}$. Specifically, $\mathrm{Na}_{3} \mathrm{VO}_{4}$ and $\mathrm{NaCN}$, which decrease the proton-induced reduction in $\left[\mathrm{Ca}^{2+}\right]_{i}$, inhibit the activity of Ca-ATPase (18) and ATP production $(21,22)$, respectively. A Ca-ATPase is known to be localized to the plasma membrane of the osteoclast (23). Although these data suggest that protons reduce $\left[\mathrm{Ca}^{2+}\right]_{\mathrm{i}}$ via stimulation of cation efflux through a $\mathrm{Ca}^{2+}$ ATPase, caution is indicated. $\mathrm{NaCN}$ by depleting cellular ATP stores may have an effect on the ability of
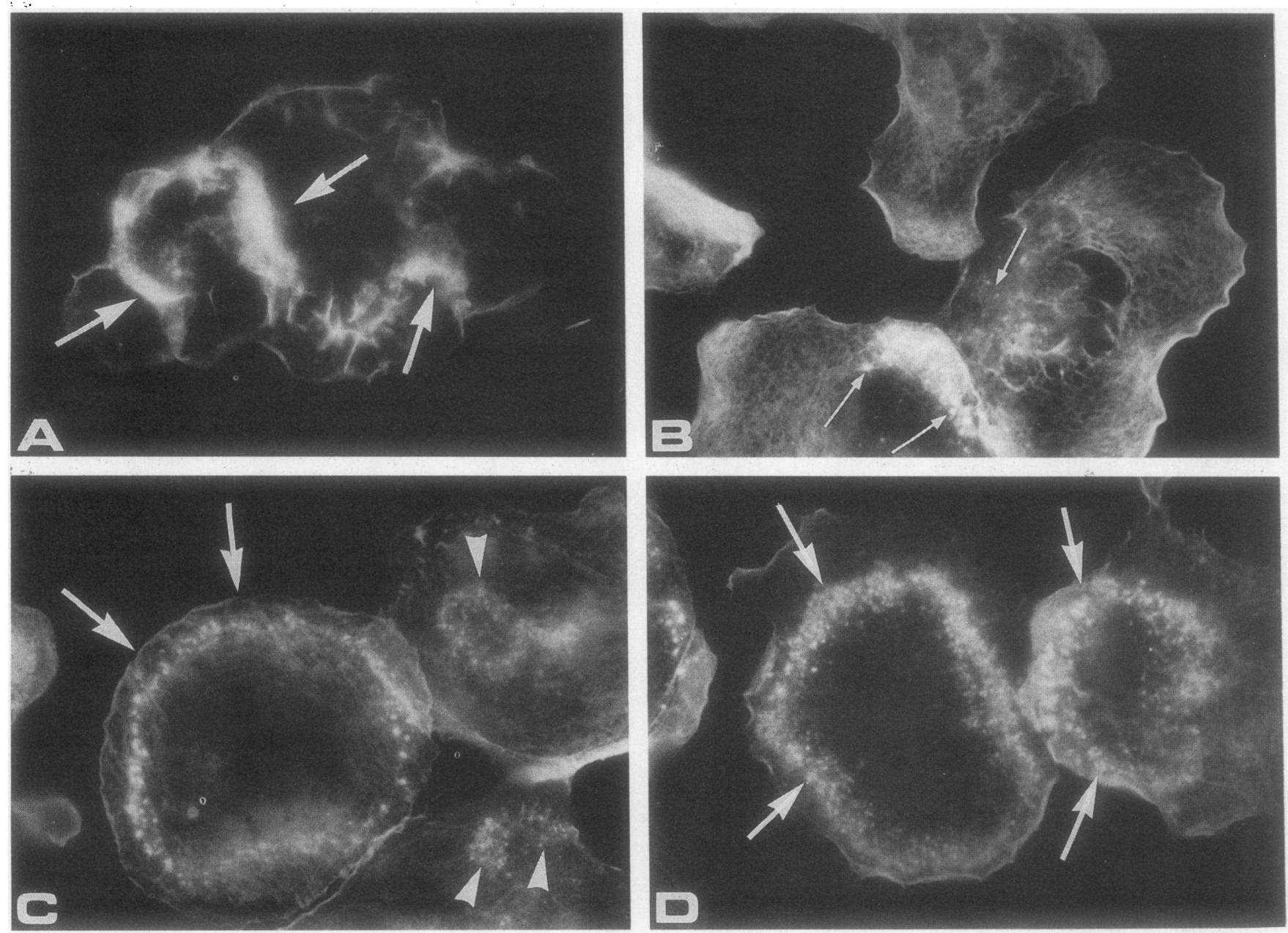

Figure 7. Fluorescence microscopy of osteoclast microfilaments detected by rhodamine phalloidin (R-PHD). $(A)$ Osteoclasts with F actin distributed in membrane ruffles (arrows). Such cells make up 66\% of $2-\mathrm{d}$ control cultures. $(B)$ Osteoclasts with $\mathrm{F}$ actin distributed in a fine network and containing a small number of podosomes (arrows). Such cells make up $43 \%$ of 2-d control cultures. ( $C$ and $D$ ) Examples of osteoclasts with well organized podosomes ( $\mathrm{Na}$ butyrate treated for $90 \mathrm{~min}$ ). In $C$, an osteoclast with a peripheral ring of podosomes (arrows) is surrounded by osteoclasts in which podosomes are scanty and organized in small clusters (arrowheads). In $D$, a well-organized clear zone containing several layers of podosomes is visible in two osteoclasts (arrows). 
A

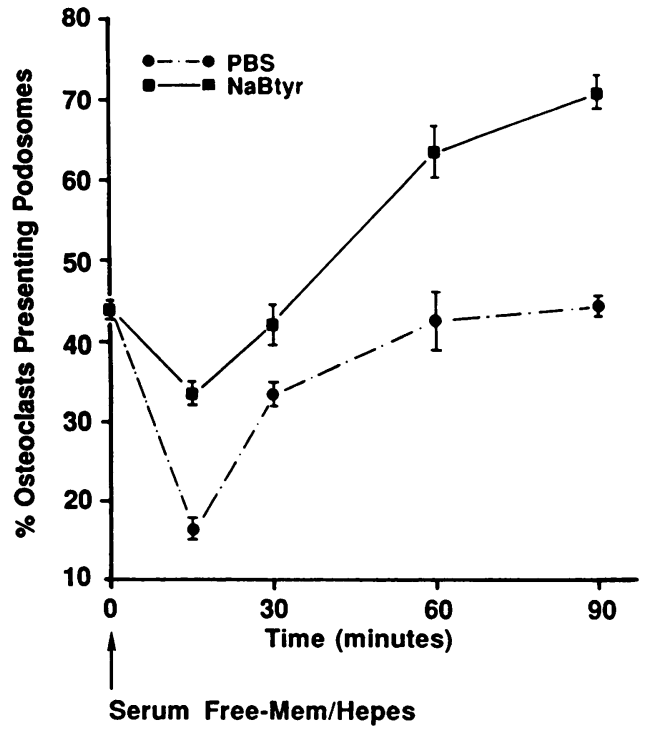

B

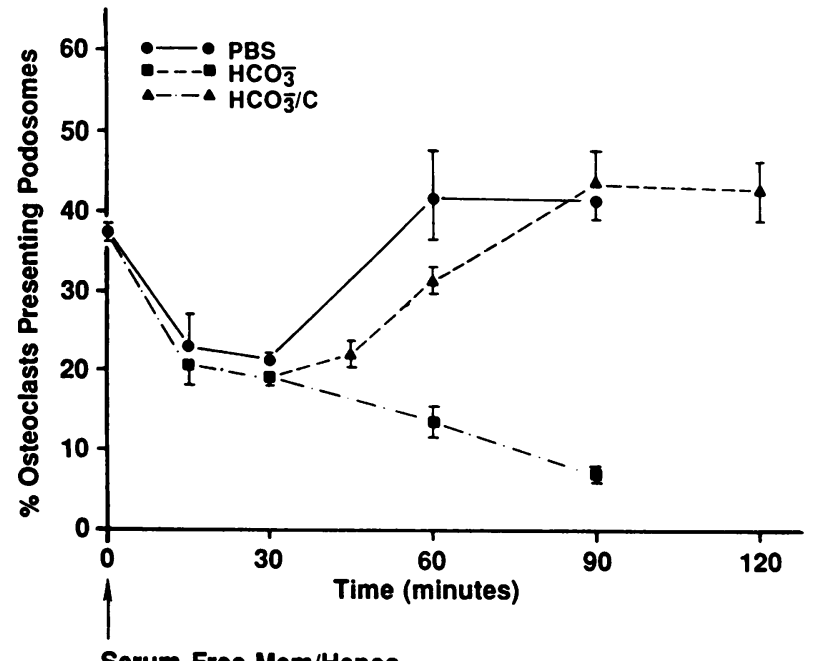

Serum Free-Mem/Hepes

Figure 8 . Effect of butyric acid and bicarbonate removal on osteoclast podosomes. $(A) \mathrm{F}$ actin organization into podosomes was evaluated at various times during incubation in control or $\mathrm{NaBtyr}$ buffers. Osteoclasts transferred to serum-free control buffer underwent a temporary $(15 \mathrm{~min})$ decrease in podosome development which returned to initial values within $60 \mathrm{~min}$. NaBtyr decreased the effect of serumfree medium and thereafter, stimulated podosome formation. (B) Bicarbonate loading produced a reversible decline in $\mathrm{F}$ actin distribution into podosomes. Removal of bicarbonate $\left(\mathrm{HCO}_{3}^{-} /[\mathrm{C}]\right.$ cells transferred from or $\mathrm{HCO}_{3}^{-}$containing buffer to a PBS control buffer) increased formation of the attachment structures to control levels, but failed to stimulate further podosome development.

organelles to sequester $\mathrm{Ca}^{2+}$, orthovanadate can inhibit $\mathrm{Na}^{+} / \mathrm{K}^{+}$ATPase (24). Thus, the possibility still exists that cation sequestration into endoplasmic reticulum may play a role in acidosis-reduced $\left[\mathrm{Ca}^{2+}\right]_{i}$. However, the compatibility of our data with other investigators $(18,25)$ demonstrating the stimulatory effect of external protons and the voltage dependency of the Ca-ATPase pump activity should be noted.

We also noted that osteoclast $\left[\mathrm{Ca}^{2+}\right]_{i}$ falls in the face of membrane depolarization, an event that is additive to the reduction in $\left[\mathrm{Ca}^{2+}\right]_{\mathrm{i}}$ induced by protons. This finding suggested that an electrogenic means of net $\mathrm{Ca}^{2+}$ efflux or $\mathrm{Ca}^{2+}$ sequestration is present in the osteoclast. As opposed to data from

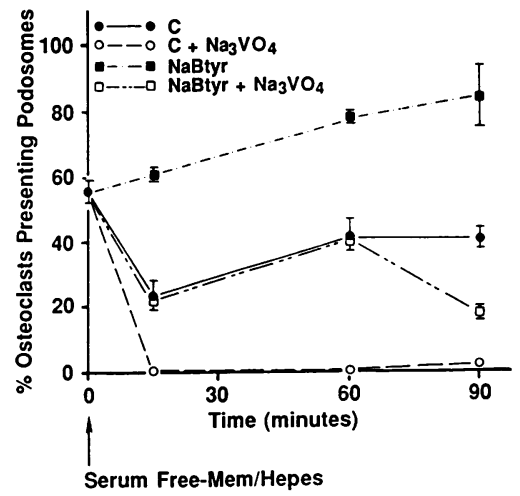

Figure 9. Effect of $\mathrm{Na}_{3} \mathrm{VO}_{4}$ on podosomes in the presence and absence of NaBtyr. Although in the PBS control buffer (C) $\mathrm{Na}_{3} \mathrm{VO}_{4}$ completely inhibited podosome expression $\left(\mathrm{C}+\mathrm{Na}_{3} \mathrm{VO}_{4}\right)$. In the presence of $\mathrm{NaBtyr}$, podosomes were still present $(\mathrm{NaBtyr}$ $\left.+\mathrm{Na}_{3} \mathrm{VO}_{4}\right)$. However, their percentage was lower than in cells

treated with NaBtyr alone. Note that in these experiments, the temporary decline in podosome expression upon changing the cells from culture media to NaBtyr was not observed.

other cell types (26), a Na ${ }^{+} / \mathrm{Ca}^{2+}$ exchange mechanism could not, in our circumstance, account for the change in cytoplasmic calcium, as the event occurred in a $\mathrm{Na}^{+}$-free environment. Furthermore, the experiments with $\mathrm{KCl}$-induced depolarization suggest that voltage-sensitive $\mathrm{Ca}^{2+}$ channels are not expressed by osteoclasts in our experimental circumstances.

Finally, and perhaps most importantly, we explored the relationship of acidification and altered $\left[\mathrm{Ca}^{2+}\right]_{i}$ to the means by which osteoclasts attach to bone, a step essential to matrix degradation $(2,10)$. We found that metabolic acid promotes formation of podosomes, $\mathrm{F}$ actin-containing, dot-like, adhesion structures, organized in a pattern suggestive of the clear zone, the actin-rich area within the cell that binds it to bone $(10,27)$. These attachment structures appear in osteoclasts exposed to agents such as retinoids (28), which stimulate resorptive activity both in vitro $(28,29)$ and in vivo $(28)$. In contrast, alkalinization of the cell which we have shown curtails resorption, leads to disappearance of podosomes, which in turn, reappear with removal of external $\mathrm{HCO}_{3}^{-}$. Interestingly, although $\mathrm{NaCN}$ or $\mathrm{Na}_{3} \mathrm{VO}_{4}$ blocked podosome formation, their effects were partially reversed by NaBtyr stimulation. Thus, they prevented full expression of the stimulatory effects of NaBtyr. This may indicate the effect of NaBtyr on an inhibited baseline, or it may indicate that the inhibitory affects of $\mathrm{VO}_{4}^{3-}$ and $\mathrm{CN}^{-}$on $\left[\mathrm{Ca}^{2+}\right]_{\mathrm{i}}$ reduction may have prevented full expression of the NaBtyr effect.

The means by which protons prompt podosome formation are unknown but may involve gelsolin, a 90-kD osteoclast-residing cytoplasmic protein $(30,31)$ that colocalizes with $F$ actin in osteoclast podosomes (11). Gelsolin binds to the barbed ends of actin filaments at a rate of $10^{7} \mathrm{M}^{-1} \mathrm{~s}^{-1}$ in the presence of $\mathrm{Ca}^{2+}$, inducing filament severing $(32,33)$, or it binds to active monomers, stimulating microfilament nucleation, with a reaction about five times faster at $\mathrm{pH} 6$ than at $\mathrm{pH}$ 8 (34). These properties, together with the direct low $\mathrm{pH}$-stimulated actin polymerization (35), could account for the acidinduced podosome formation in osteoclasts.

Thus, exposure of osteoclasts to an acidic microenvironment establishes a series of rapid intracellular events which, in early stages, involves ion transport and ultimately, morphological changes associated with bone resorption. It is therefore significant that we have recently established that pure populations of isolated osteoclasts respond to reduction in extracellular $\mathrm{pH}$ with enhanced resorptive activity, documenting a direct effect of protons on the bone-degrading capacity of the cell 
(Carono, A., manuscript in preparation) in agreement with the results of Arnett and Dempster (9).

\section{Acknowledgments}

This work was supported by National Institutes of Health grant AM-32788 (S. L. Teitelbaum), AR-01631 (H. C. Blair), AR-39561, and AR-32087 (K. A. Hruska); a grant from the Shriners Hospital for Crippled Children (St. Louis Unit), and grants from Ministero della Pubblica Istruzione (MPI) (A. Teti and A. Zambonin-Zallone).

\section{References}

1. Baron, R., L. Neff, D. Louvard, and P. J. Courtoy. 1985. Cellmediated extracellular acidification and bone resorption: evidence for a low $\mathrm{pH}$ in resorbing lacunae and localization of a $100-\mathrm{kD}$ lysosomal membrane protein on the osteoclast ruffled border. J. Cell Biol. 101:2210-2222.

2. Blair, H. C., A. J. Kahn, E. C. Crouch, J. J. Jeffrey, and S. L. Teitelbaum. 1986. Isolated osteoclasts resorb the organic and inorganic components of bone. J. Cell Biol. 102:1164-1172.

3. Chambers, T. J., P. M. McSheehy, B. M. Thomson, and K. Fuller. 1985. The effect of calcium-regulating hormones and prostaglandins on bone resorption by osteoclasts disaggregated from neonatal rabbit bones. Endocrinology. 116:234-239.

4. Hunter, S. J., H. Schraer, and C. V. Gay. 1988. Characterization of isolated and cultured chick osteoclasts: the effect of acetazolomide, calcitonin and parathyroid hormone on acid production. J. Bone Miner. Res. 3:297-303.

5. Anderson, R. E., D. M. Woodbury, and W. S. S. Jee. 1986. Humoral and ionic regulation of osteoclast activity. Calcif. Tissue Int. 39:252-258.

6. Bushinsky, D. A., J. Golding, and F. L. Coe. 1985. Cellular contribution to $\mathrm{pH}$-mediated calcium flux in neonatal mouse calvaria. Am. J. Physiol. 248:F785-F789.

7. Chan, Y. L., E. Savdie, R. S. Mason, and S. Posen. 1985. The effect of metabolic acidosis on vitamin $\mathrm{D}$ metabolites and bone histology in uremic rats. Calcif. Tissue Int. 37:158-164.

8. Goldhabe, P., and L. Rabajija. 1987. $\mathrm{H}^{+}$stimulation of cell mediated bone resorption in tissue culture. Am. J. Physiol. 253:E90E98.

9. Arnett, T. R., and D. W. Dempster. 1986. Effect of $\mathrm{pH}$ on bone resorption by rat osteoclasts in vitro. Endocrinology. 119:119-124.

10. Marchisio, P. C., D. Cirillo, L. Naldini, M. V. Primavera, A. Teti, and A. Zambonin Zallone. 1984. Cell-substratum interaction of cultured avian osteoclasts is mediated by specific adhesion structures. J. Cell Biol. 99:1696-1705.

11. Marchisio, P. C., D. Cirillo, A. Teti, A. Zambonin Zallone, and G. Tarone. 1987. Rous sarcoma virus-transformed fibroblasts and cells of monocytic origin display a peculiar dot-like organization of cytoskeletal proteins involved in microfilament-membrane interaction. Exp. Cell Res. 169:202-214.

12. Zambonin Zallone, A., A. Teti, A. Carano, and P. C. Marchisio. 1988. The distribution of podosomes in osteoclasts cultured on bone laminae: effect of retinol. J. Bone Miner. Res. 5:517-523.

13. Zambonin Zallone, A., A. Teti, M. Grano, A. Rubinaeei, M. Abbadini, M. Gaboli, and P. C. Marchisio. 1989. Immunocytochemical distribution of extracellular matrix receptors in human osteoclasts: a $\beta_{3}$ integrin is co-localized with vinculin and talin in the podosomes of osteoclastoma giant cells. Exp. Cell Res. In press.

14. Zambonin Zallone, A., A. Teti, and M. V. Primavera. 1982. Isolated osteoclasts in primary culture: first observations on structure and survival in culture media. Anat. Embryol. 165:405-413.14.
15. Teti, A., H. C. Blair, S. L. Teitelbaum, A. J. Kahn, C. Koziol, J. Konsek, A. Zambonin Zallone, and P. H. Schlesinger. 1989. Cytoplasmic $\mathrm{pH}$ regulation and chloride/bicarbonate exchange in avian osteoclasts. J. Clin. Invest. 83:227-233.

16. Grynkiewicz, G., M. Poenie, and R. Y. Tsien. 1985. A new generation of $\mathrm{Ca}^{2+}$ indicators with greatly improved fluorescence properties. J. Biol. Chem. 260:3440-3450.

17. Wulf, E., A. Deboden, F. A. Bautz, H. Faulstich, and T. Wieland. 1979. Fluorescent phallotoxin, a tool for the visualization of cellular actin. Proc. Natl. Acad. Sci. USA. 76:4498-4502.

18. Carafoli, E., and M. Zurini. 1982. The $\mathrm{Ca}^{2+}$-pumping ATPase of plasma membranes purification, reconstitution and properties. Biochim. Biophys. Acta. 683:279-301.

19. Blair, H. C., S. L. Teitelbaum, R. Ghiselli, and S. Gluck. Osteoclasts resorb bone using polarized $\mathrm{H}^{+}$secretion by a vacuolar proton pump. Science (Wash. DC). In press.

20. Dominguez, J. H. and L. G. Raisz. 1979. Effects of changing hydrogen ion, carbonic acid, and bicarbonate concentrations on bone resorption in vitro. Calif. Tissue Int. 29:7-13.

21. Baker, P. F. 1986. Strategies for $\mathrm{Ca}^{2+}$ coupling in neurons. In Ion Channels in Neural Membranes. J. M. Ritchie, R. R. Keines, L. Bolis, editors. Alan R. Liss Inc., New York. 177-192.

22. Baker, P. F., and D. E. Knight. 1986. Exocytosis: control by $\mathrm{Ca}^{2+}$ and other factors. Br. Med. Bull. 42:399-404.

23. Akisaka, T., T. Yamamoto, and C. V. Gay. 1988. Ultracytochemical investigation of calcium-activated triphosphatase $\mathrm{CCa}^{2+}$ ATPase) in chick tibia. Bone Min. Res. 3:19-25.

24. Cantley, L. C., M. Resh, and G. Guidotti. 1978. Vanadate inhibits the red-cell $\left(\mathrm{Na}^{+}+\mathrm{K}^{+}\right)$ATPase from the cytoplasmic side. Nature (Lond.). 272:552-554.

25. Gassner, B., S. Luterbacher, H. J. Schatzmann, and A. Wuthrich. 1988. Dependence of the red blood cell calcium pump on the membrane potential. Cell Calcium. 9:95-103.

26. Shoback, D. M., and E. M. Brown. 1984. PTH release stimulated by high extracellular potassium is associated with a decrease in cytosolic calcium in bovine parathyroid cells. Biochem. Biophys. Res. Commun. 123:684-690.

27. Miller, S. C. 1977. Osteoclast cell-surface changes during egglaying cycle in Japanese quail. J. Cell Biol. 75:104-118.

28. Oreffo, R. O. C., A. Teti, T. J. Triffitt, M. J. O. Francis, A. Carano, and A. Zambonin Zallone. 1988. Effect of vitamin A on bone resorption: evidence for direct stimulation of isolated chicken osteoclasts by retinol and retinoic acid. J. Bone Min. Res. 3:203-210.

29. Hough, S., L. V. Avioli, H. Muir, D. Gelderblom, G. Jenkins, H. Kurasi, E. Slatopolsky, M. A. Bergfeld, and S. L. Teitelbaum. 1988. Effects of hypervitaminosis A on the bone and mineral metabolism of the rat. Endocrinology. 122:2933-2939.

30. Yin, H. L., J. H. Albrecht, and A. Fattoum. 1981. Identification of gelsolin, $\mathrm{a} \mathrm{Ca}^{2+}$-dependent regulatory protein of actin gel-sol transformation, and its intracellular distribution in a variety of cells and tissues. J. Cell Biol. 91:901-906.

31. Yin, H. L., and T. P. Stossel. 1980. Purification and structural properties of gelsolin, $\mathrm{Ca}^{2+}$-activated regulatory protein of macrophages. J. Biol. Chem. 255:9490-9493.

32. Bryan, J., and L. M. Coluccio. 1985. Kinetic analysis of F-actin depolymerization in the presence of platelet gelsolin and gelsolin-actin complexes. J. Cell Biol. 101:1236-1244.

33. Chaponnier, C., P. A. Yanmey, and H. L. Yin. 1986. The actin filament-severing domain of plasma gelsolin. J. Cell Biol. 103:14731481 .

34. Selve, N., and A. Wegner. 1987. pH-dependent rate of formation of gelsolin-actin complex from gelsolin and monomeric actin. Eur. J. Biochem. 168:111-115.

35. Zimmerle, C. T., and C. Frieden. 1988. Effect of pH on the mechanism of actin polymerization. Biochemistry. 27:7766-7772. 